\title{
KAJIAN PENAMBAHAN PATI KENTANG (Solanum tuberosum L.) TERHADAP KARAKTERISTIK SOSIS DAGING SAPI
}

\section{Study Of Additional Potato Start (Solanum Tuberosum L.) On The Characteristics Of Beef Sausage}

\author{
Macicha Elvira Yuniar*, Dewi Nur Azizah \\ Program Studi Pendidikan Teknologi Agroindustri, FPTK, Universitas Pendidikan Indonesia \\ JI. Dr. Setiabudi No. 229, Bandung 40154 Jawa Barat - Indonesia \\ *Penulis Korespondensi, Email: macichaelviray@upi.edu
}

\begin{abstract}
ABSTRAK
Sosis merupakan produk olahan daging yang memiliki nilai gizi tinggi. Pada pembuatan sosis diperlukan bahan tambahan lain sebagai pengisinya. Pati kentang memiliki kadar amilopektin sebesar $78.96 \%$ yang baik dalam pembentukan tekstur apabila digunakan sebagai bahan pengisi. Tujuan dari penelitian ini adalah untuk mengetahui karakteristik sosis daging sapi dengan penambahan pati kentang dan mengetahui konsentrasi pati kentang yang tepat untuk menghasilkan produk dengan karakteristik yang baik dan disukai panelis. Desain penelitian yang digunakan terdiri dari satu faktor yaitu perbedaan konsentrasi pati kentang dengan 4 perlakuan $(10 \% ; 20 \% ; 30 \% ; 40 \%$ ) dan 1 ulangan. Secara keseluruhan, karakteristik sosis daging sapi dengan penambahan pati kentang memiliki warna merah dan berbintik, aroma daging dan rempah, tekstur kenyal, dan rasa gurih. Sosis daging sapi dengan konsentrasi pati kentang $30 \%$ memperoleh nilai rata-rata tertinggi terhadap kesukaan panelis pada seluruh atribut yang meliputi warna, aroma, tekstur, dan rasa.
\end{abstract}

Kata kunci: Pati kentang, Sosis daging sapi, Uji hedonik

\section{ABSTRACT}

Sausage is a processed meat product that has high nutritional value. In making sausages, other additional ingredients are needed as a filling. Potato starch has amylopectin content of $78.96 \%$ which is good for texture formation when used as a filler. The purpose of this study was to determine the characteristics of beef sausage with the addition of potato starch and determine the right concentration of potato starch to produce a product with good characteristics and favored by the panelists. The research design used consisted of one factor, namely the difference in the concentration of potato starch with 4 treatments (10\%;20\%; 30\%; $40 \%)$ and 1 replication. Overall, the characteristics of beef sausage with the addition of potato starch have a red and speckled color, aroma of meat and spices, chewy texture, and savory taste. Beef sausage with a potato starch concentration of $30 \%$ obtained the highest average value for the preference of the panelists on all attributes including color, aroma, texture, and taste.

Keywords: Beef sausage, Hedonic test, Potato starch

\section{PENDAHULUAN}

Salah satu produk pangan yang dikenal masyarakat dan memiliki nilai gizi tinggi adalah sosis. Menurut Zurriyati (2011), sosis merupakan salah satu produk daging giling diberi bumbu serta dimasukkan ke dalam casing atau selongsong menjadi bentuk silindris. Pada proses pembuatan sosis diperlukan bahan tambahan lain sebagai pengisinya. Menurut 
Sofyan (2018), penambahan bahan pengisi (filler) pada produk daging dapat meningkatkan stabilitas, citarasa, daya ikat air, karakteristik irisan produk, serta dapat mengurangi biaya formulasi produk daging. Pati merupakan bahan pengisi yang paling umum digunakan pada sosis.

Dalam pembuatan sosis, bahan pengisi yang umum ditambahkan adalah tapioka atau pati dari singkong. Tidak hanya dalam pembuatan sosis, tapioka juga banyak digunakan pada produk olahan pangan lainnya. Semakin beragamnya produk makanan berbasis tapioka, semakin meningkat permintaan tapioka. Solusi yang dapat dilakukan adalah dengan memanfaatkan pati dari komoditas lokal lainnya. Komoditas lokal yang dapat dimanfaatkan adalah jenis umbi-umbian.

Jenis umbi-umbian lokal sangat beragam dan melimpah, tetapi belum dimanfaatkan secara optimal oleh masyarakat, misalnya kentang. Cara mengonsumsi kentang di masyarakat masih sebatas perebusan dan pengukusan. Selain itu, Indonesia merupakan salah satu negara dengan penghasil kentang terbesar di Asia Tenggara (Niken H. dan Adepristian Y., 2013). Pada tahun 2018, produksi kentang di Indonesia mencapai angka $1,284,762$ ton (Badan Pusat Statistik, 2018). Senyawa pati termasuk ke dalam senyawa karbohidrat yang banyak terkandung di dalam umbi kentang (Maulida, 2018). Adapun hasil penelitian yang telah dilakukan oleh Niken H. dan Adepristian Y. (2013) menunjukkan bahwa secara berturut-turut kadar amilosa dan amilopektin yang dimiliki kentang adalah sebesar $21.04 \%$ dan $78.96 \%$. Kelebihan dari pati kentang yaitu memiliki kisaran suhu gelatinisasi yang lebih tinggi $\left(58-66^{\circ} \mathrm{C}\right)$ dibandingkan dengan tapioka $\left(52-64^{\circ} \mathrm{C}\right)$ sehingga pati kentang lebih tahan panas dibandingkan dengan tapioka (Hidayat, Ahza, dan Sugiyono, 2007).

Berdasarkan latar belakang diatas, maka perlu dilakukan penelitian penggunaan pati kentang sebagai pengganti tapioka yang bertujuan untuk mengetahui karakteristik sosis daging sapi dengan penambahan pati kentang dan mengetahui konsentrasi pati kentang yang tepat digunakan untuk menghasilkan sosis daging sapi dengan karakteristik yang baik dan disukai panelis.

\section{BAHAN DAN METODE}

\section{Bahan}

Dalam pembuatan sosis, bahan dasar yang digunakan yaitu daging sapi bagian paha dan pati kentang kemasan merk Mr. Food, sedangkan bahan tambahannya adalah susu skim, gula halus, bawang putih bubuk, lada putih, pala, garam, angkak, STTP (Sodium Tripoly Phosphate), minyak nabati, air es, dan selongsong sosis polyamide.

\section{Alat}

Alat yang digunakan dalam membuat produk dan uji hedonik adalah sendok, pisau stainless steel, talenan, saringan, mangkuk, baskom, panci, cobek dan ulekan, chopper, timbangan, kompor, piping bag, dan benang.

\section{Desain Penelitian}

Penelitian ini terdiri dari satu faktor, yaitu konsentrasi pati kentang yang terdiri dari empat perlakuan. Konsentrasi pati kentang yang ditambahkan pada pembuatan sosis adalah sebesar 10, 20, 30, dan 40\% dari total berat daging sapi yang digunakan.

\section{Tahapan Penelitian}

Pembuatan sosis daging sapi dilakukan melalui beberapa tahapan sesuai penelitian yang dilakukan oleh Atma (2015) dengan menggunakan formula yang sudah dimodifikasi. Langkah pertama yang dilakukan adalah memilih daging sapi yang segar, kemudian pemisahan lemak dan jaringan ikatnya. Setelah itu dilakukan penimbangan, pencucian, dan pemotongan. Selanjutnya pencampuran pada tahap pertama dengan air es (40\%) dan penghalusan ( $<3$ menit). Tahap kedua pencampuran dengan garam (3\%) basis berat daging 
sapi dan pati kentang, STTP $(0,5 \%)$, dan minyak nabati $(5 \%)$ dan penghalusan $(<2$ menit). Tahap ketiga pencampuran dengan pati kentang (sesuai perlakuan), susu skim (5\%), bawang putih bubuk (3\%), gula (3\%), lada putih (1\%), pala $(0.3 \%)$, dan angkak (1\%). Setelah itu, pencetakan adonan ke dalam selongsong dan perebusan pada suhu $90^{\circ} \mathrm{C}$ selama 40 menit. Selanjutnya pendinginan sosis dengan perendaman pada air dingin selama \pm 2 menit.

\section{Metode}

Penelitian yang digunakan berupa metode percobaan (experimental method). Data yang dihasilkan ditabulasikan dan dianalisis secara deskriptif kualitatif.

\section{Prosedur Analisis}

Karakteristik sosis daging sapi dilakukan dengan uji organoleptik. Pengujian organoleptik dilakukan dengan menggunakan uji hedonik atau uji kesukaan. Data yang diperoleh berasal dari panelis tidak terlatih sebanyak 6 orang. Pada uji hedonik, panelis disajikan sampel sosis daging sapi dengan penambahan pati kentang dengan 4 kode berbeda, yaitu $343,244,421$, dan 311 . Setelah itu, panelis diminta untuk mencicipi setiap sampel dan memberikan penilaian yang meliputi warna, aroma, tekstur, dan rasa pada formulir uji hedonik yang telah disediakan.

\section{HASIL DAN PEMBAHASAN}

\section{Karakteristik Sosis Daging Sapi}

Dalam pembuatan sosis ini, bahan baku utama yang digunakan antara lain daging sapi dan pati kentang. Perbedaaan konsentrasi bahan baku yang digunakan dapat menghasilkan karakteristik produk yang berbeda pula. Karakteristik sosis daging sapi yang dihasilkan tersaji dalam Tabel 1.

\section{Warna}

Penambahan pati kentang dengan berbagai konsentrasi dapat memberikan perbedaan warna sosis daging sapi yang dihasilkan (Tabel 1). Berdasarkan uji organoleptik, sosis daging sapi dengan konsentrasi pati kentang $10 \%$ menghasilkan produk yang paling merah dibandingkan dengan perlakuan lainnya. Semakin tinggi konsentrasi pati kentang yang ditambahkan, intensitas warna sosis daging sapi yang dihasilkan semakin berkurang atau semakin tidak kemerahan.

Sosis daging sapi yang dihasilkan pada setiap perlakuan memiliki warna kemerahan dan berbintik. Warna merah yang dihasilkan pada sosis daging sapi ini berasal dari adanya penambahan angkak selama proses pengolahan, sedangkan bintik merah yang dihasilkan diakibatkan oleh butir-butir angkak yang kurang halus. Menurut Wahyuni, Setiyono, dan Supadmo (2012), sosis daging sapi tanpa penambahan angkak akan menghasilkan warna abu-abu agak kecoklatan. Angkak merupakan salah satu pewarna berbahan dasar alami yang dapat dimanfaatkan dalam pembuatan sosis (Timotious, 2004). Pada penelitian ini, angkak yang ditambahkan pada setiap perlakuan sebanyak $1 \%$ dan hanya menggunakan basis dari berat daging sapi yang digunakan, sehingga warna yang dihasilkan dapat tertutupi atau lebih pucat apabila konsentrasi pati kentang sebagai bahan pengisi yang digunakan semakin banyak. Pemucatan warna daging sosis sapi dapat juga dipengaruhi oleh suhu. Pengaruh suhu dapat mengakibatkan zat warna mengalami dekomposisi dan perubahan pada strukturnya. Sebaiknya suhu yang digunakan pada pengolahan yang melibatkan penggunaan pigmen angkak tidak melebihi $150^{\circ} \mathrm{C}$ (Atma, 2015).

Berdasarkan SNI No. 3820, syarat mutu sosis daging adalah berwarna normal, yaitu tidak memiliki warna merah terang dan juga tidak terlalu pucat (Badan Standardisasi Nasional, 2015). Sosis daging sapi yang dihasilkan memiliki warna kemerahan. Warna sosis daging sapi yang dihasilkan telah sesuai dengan SNI. 
Tabel 1. Karakteristik Sosis Daging Sapi

\section{Konsentrasi}

Pati Kentang

\section{Deskripsi Sosis Daging Sapi}

\section{Foto}

Berwarna kemerahan dengan bintik merah, sangat beraroma daging dan terdapat aroma rempah, tekstur agak tidak kenyal dan berserat, dan rasa sangat gurih.

Berwarna agak tidak kemerahan dengan bintik merah, beraroma daging dan terdapat aroma rempah, tekstur kenyal, berserat, dan berongga, serta rasa sangat gurih.

Berwarna agak tidak kemerahan dengan bintik merah, beraroma daging dan terdapat aroma rempah, tekstur kenyal dan agak tidak berserat, serta rasa gurih.

Berwarna sangat tidak kemerahan dengan bintik merah, agak tidak beraroma daging dan agak beraroma tepung, tekstur amat sangat kenyal, agak kering, dan berongga, serta rasa agak tidak gurih.

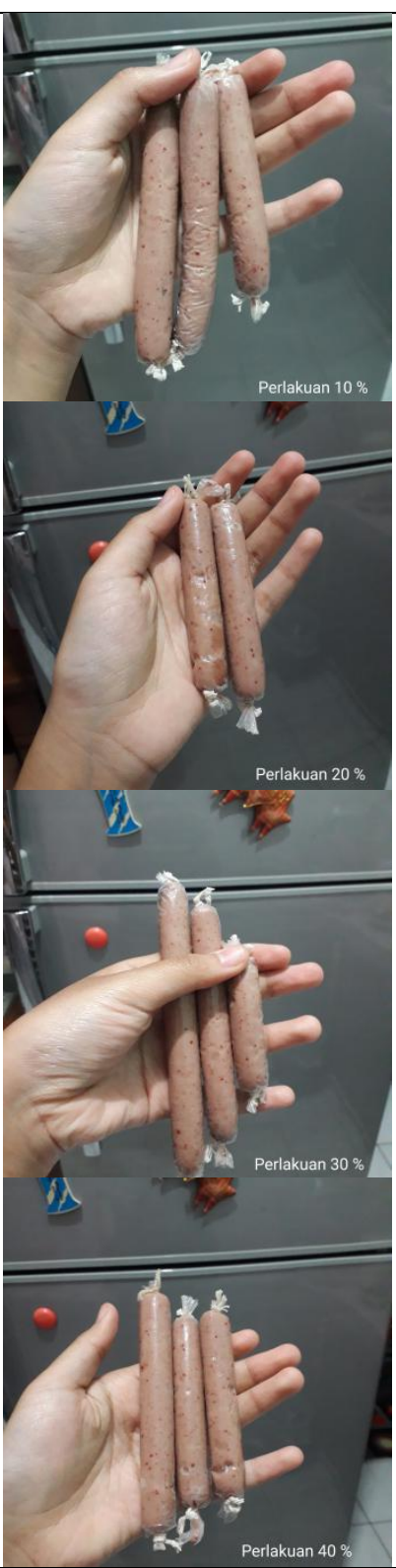

\section{Aroma}

Berdasarkan uji organoleptik, aroma sosis daging sapi didominasi oleh aroma daging sapi yang digunakan (Tabel 1). Penambahan pati kentang yang berbeda dapat memberikan perbedaan aroma pada setiap perlakuan. Seiring dengan konsentrasi pati kentang yang semakin tinggi mengakibatkan ketajaman aroma sosis daging sapi yang dihasilkan akan semakin berkurang karena aroma daging akan tertutupi oleh penggunaan bahan pengisi yang semakin banyak.

Aroma sosis daging sapi yang dihasilkan tidak hanya berasal dari daging, tetapi dipengaruhi juga oleh bahan lain yang dicampurkan ke dalam adonan sosis misalnya bahan penyedap atau bumbu. Bumbu merupakan bahan aromatik yang ditimbulkan oleh senyawasenyawa volatil kompleks (Zurriyati, 2011; Ariyani, 2006). Pada pembuatan sosis daging sapi ini bahan-bahan lain yang ditambahkan menggunakan komposisi yang sama. Namun karena konsentrasi bahan pengisi yang digunakan berbeda, sehingga dapat mempengaruhi karakteristik aroma sosis daging sapi yang dihasilkan. Bahan pengisi yang digunakan berupa 
pati kentang yang memiliki aroma seperti tepung. Hal ini ditunjukkan pada perlakuan $40 \%$ yang menghasilkan aroma agak tidak beraroma daging, sehingga sosis daging sapi yang dihasilkan memiliki sedikit aroma tepung.

Berdasarkan SNI No. 3820, syarat mutu sosis daging adalah beraroma normal, yaitu tidak adanya aroma yang mengganggu (Badan Standardisasi Nasional, 2015). Sosis daging sapi yang dihasilkan memiliki aroma daging dan rempah. Aroma sosis daging sapi yang dihasilkan telah sesuai dengan SNI.

\section{Tekstur}

Penambahan pati kentang dengan berbagai konsentrasi dapat memberikan perbedaan tekstur sosis daging sapi yang dihasilkan (Tabel 1). Seiring dengan konsentrasi pati kentang yang semakin tinggi mengakibatkan tekstur sosis daging sapi yang dihasilkan semakin kenyal. Sosis daging sapi dengan konsentrasi pati kentang $10 \%$ menghasilkan tekstur agak tidak kenyal, sedangkan sosis daging sapi dengan konsentrasi pati kentang 40\% menghasilkan tekstur amat sangat kenyal. Prastini dan Widjanarko (2015) mengatakan bahwa tekstur sosis dapat dipengaruhi oleh semakin banyaknya bahan tambahan yang dimasukkan dalam pembuatan sosis bahkan sifat khas dari sosis tersebut juga dapat hilang.

Sosis yang berada di pasaran biasanya menggunakan bahan pengisi berupa tapioka. Tinggi rendahnya kadar amilosa dan amilopektin pada bahan pengisi dapat mempengaruhi kekenyalan pada sosis. Tapioka mengandung kadar amilosa sebesar $17.41 \%$ dan kadar amilopektin sebesar 82.13\% (Gumilar, Rachmawan, dan Nurdyanti, 2011), sedangkan kadar amilosa dan amilopektin pati kentang secara berturut-turut adalah sebesar $21.04 \%$ dan 78.96\% (Niken H. dan Adepristian Y., 2013). Pembentukan sifat kekenyalan merupakan potensi dari adanya bentukan daya lengket yang kuat dari tingginya kadarnya amilopektin (Faturohman, Susilo, dan Mustakim, 2018). Semakin tinggi kandungan amilopektin, semakin meningkat kekenyalan produk. Hal tersebut sejalan dengan penelitian Faturohman et al., (2018) bahwa bakso daging kelinci dengan penggunaan tapioka menghasilkan nilai kekerasan yang rendah dibandingkan dengan bakso daging kelinci dengan penambahan pati kentang. Hal tersebut dapat diartikan bahwa produk yang menggunakan tapioka menghasilkan nilai kekenyalan yang lebih tinggi dibandingkan dengan penggunaan pati kentang pada konsentrasi yang sama.

Bahan pengisi (filler) yang digunakan dalam proses pembuatan sosis akan mengikat air. Kandungan pati yang cukup tinggi dapat menyerap air hingga melebihi kapasitas sehingga tekstur produk akan menjadi kering (Atma, 2015). Sosis daging sapi dengan konsentrasi pati kentang terendah (10\%) memiliki tekstur lebih berserat dan cenderung basah, sedangkan pada konsentrasi pati kentang tertinggi (40\%) memiliki tekstur cenderung lebih kering. Ahmadi, Afrila, dan Adhi (2007) juga mengungkapkan bahwa penambahan jumlah pati kentang dalam proses pembuatan sosis daging sapi dapat menurunkan persentase kadar air sosis, karena ikatan hidrogen telah digunakan untuk mekanisme ikatan pati dengan protein pada daging sehingga air yang ada tidak dapat diserap secara maksimal. Pada konsentrasi pati kentang $20 \%$ dan $40 \%$ menghasilkan sosis berongga pada bagian tengahnya. Hal ini disebabkan oleh sulitnya proses pengisian ke dalam selongsong karena ukuran selongsong yang digunakan cukup kecil.

\section{Rasa}

Penambahan pati kentang dengan berbagai konsentrasi dapat memberikan perbedaan rasa sosis daging sapi yang dihasilkan (Tabel 1). Berdasarkan uji hedonik, sosis daging sapi dengan konsentrasi pati kentang 10, 20, 30, dan 40\% secara berturut-turut menghasilkan rasa sangat gurih, gurih, dan agak tidak gurih. Seiring dengan konsentrasi pati kentang yang semakin tinggi mengakibatkan intensitas rasa sosis daging sapi yang dihasilkan semakin berkurang.

Secara keseluruhan sosis daging sapi didominasi oleh rasa gurih yang berasal dari daging dan bahan penyedap, sedangkan bahan pengisi berupa pati kentang cenderung memiliki rasa yang hambar. Bahan penyedap seperti bawang putih, lada, pala, gula, dan 
garam memberikan cita rasa yang enak pada produk. Bahan penyedap yang ditambahkan dapat memberikan rasa yang khas dikarenakan terdapat kandungan volatil didalamnya.

Formulasi bahan penyedap dan bahan pengisi untuk pembuatan sosis berpengaruh terhadap rasa produk yang dihasilkan (Zurriyati, 2011). Pada penelitian ini, bahan penyedap yang ditambahkan pada setiap perlakuan memiliki jumlah yang sama dan hanya menggunakan basis dari berat daging yang digunakan, sehingga rasa yang dihasilkan dapat tertutupi atau semakin tidak terasa apabila konsentrasi pati kentang sebagai bahan pengisi yang digunakan semakin banyak. Prayitno et al. (2009) juga mengatakan bahwa adanya penambahan bahan pengisi dapat menurunkan cita rasa sosis. Perubahan tekstur yang diakibatkan oleh penambahan bahan pengisi juga dapat mengakibatkan rasa yang dihasilkan berubah karena dapat mempengaruhi kecepatan timbulnya rangsangan terhadap sel reseptor olfaktori dan kelenjar air liur (Winarno, 1997).

Sesuai dengan SNI No. 3820, syarat mutu sosis daging adalah memiliki rasa yang normal, yaitu tidak terasa asing (Badan Standardisasi Nasional, 2015). Sosis daging sapi yang dihasilkan tergolong memiliki rasa yang gurih. Rasa sosis daging sapi yang dihasilkan telah sesuai dengan SNI.

\section{Pengujian Organoleptik}

Pengujian organoleptik menggunakan uji hedonik dilakukan pada sosis daging sapi dengan tujuan untuk mengetahui tingkat kesukaan panelis terhadap produk yang dihasilkan. Parameter yang diuji dalam sosis daging sapi ini antara lain parameter warna, aroma, tekstur, dan rasa.

\section{Warna}

Salah satu sifat dan sensoris produk makanan yang utama adalah warna. Pada umumnya, warna menjadi parameter yang utama bagi konsumen dalam memilih suatu produk makanan. Nilai rata-rata panelis terhadap warna sosis daging sapi dapat dilihat pada Gambar 1.

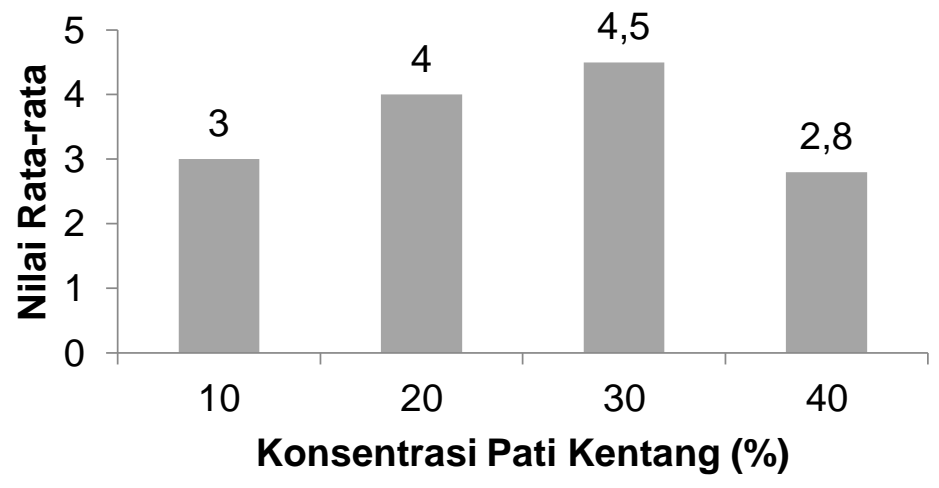

Gambar 1. Nilai Rata-rata Kesukaan Warna

Dari grafik pada Gambar 1 diatas, nilai rata-rata panelis terhadap kesukaan warna berkisar antara 2.8-4.5 (tidak suka-sangat suka). Nilai rata-rata terendah sebesar 2.8 dengan karakteristik produk sangat tidak kemerahan diperoleh dari sosis daging sapi dengan konsentrasi pati kentang $40 \%$, sedangkan nilai rata-rata tertinggi sebesar 4.5 dengan karakteristik produk agak tidak kemerahan diperoleh dari sosis daging sapi dengan konsentrasi pati kentang 30\%.

Sosis daging sapi dengan konsentrasi pati kentang 30\% memiliki warna hampir mendekati warna sosis yang ada di pasaran, sehingga sosis ini paling disukai oleh panelis. Panelis menganggap konsentrasi pati kentang 30\% sudah cukup baik untuk menghasilkan warna yang disukai. Apabila konsentrasi pati kentang sebagai bahan pengisi yang digunakan semakin banyak maka warna yang dihasilkan dapat lebih pucat begitu pula sebaliknya. Sebab, angkak yang ditambahkan pada setiap perlakuan sebanyak $1 \%$ hanya menggunakan basis dari berat daging sapi. 


\section{Aroma}

Aroma ialah sensasi pada produk olahan daging yang saling mengikat dan kompleks (Prayitno et al., 2009). Aroma pada suatu produk dapat muncul selama pemasakan. Nilai ratarata panelis terhadap aroma sosis daging sapi dapat dilihat pada Gambar 2.

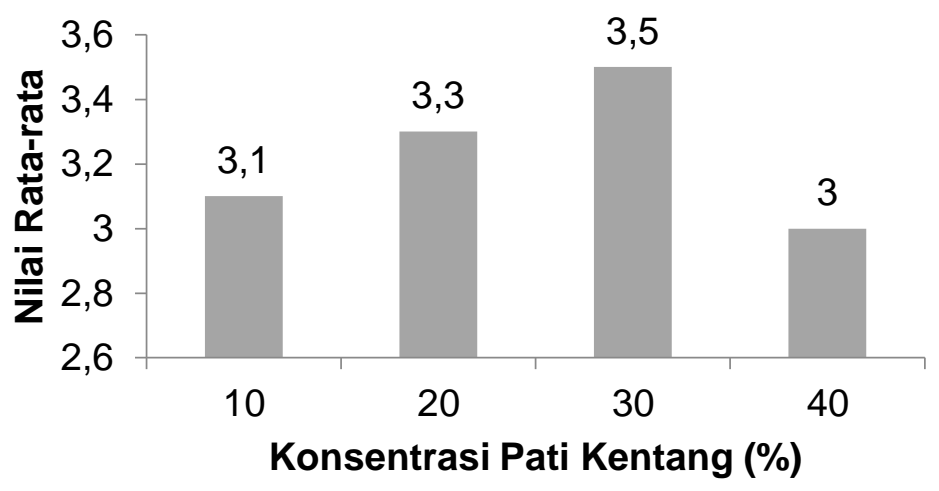

Gambar 2. Nilai Rata-rata Kesukaan Aroma

Dari grafik pada Gambar 2 diatas, nilai rata-rata panelis terhadap kesukaan aroma berkisar antara 3.0-3.5 (biasa-suka). Nilai rata-rata terendah sebesar 3.0 dengan karakteristik produk agak tidak beraroma daging diperoleh dari sosis daging sapi dengan konsentrasi pati kentang sebesar $40 \%$, sedangkan nilai rata-rata tertinggi sebesar 3.5 dengan karakteristik produk beraroma daging diperoleh dari sosis daging sapi dengan konsentrasi pati kentang $30 \%$.

Sosis daging sapi dengan konsentrasi pati kentang 30\% memiliki aroma normal, yaitu aroma daging yang tidak terlalu menyengat dan juga tidak adanya aroma bahan lain yang mengganggu, sehingga sosis ini lebih disukai oleh panelis. Panelis menganggap konsentrasi pati kentang 30\% sudah cukup baik untuk menghasilkan aroma yang disukai. Konsentrasi pati kentang yang rendah mengakibatkan aroma daging sapi yang menyengat sehingga kurang disukai oleh panelis. Begitu pula sebaliknya, aroma daging akan tertutupi apabila penggunaan bahan pengisi yang semakin banyak.

\section{Tekstur}

Sifat sensoris daging yang berkaitan dengan tingkat kekenyalan pada produk sosis adalah tekstur. Sedangkan kekenyalan merupakan kemampuan makanan untuk kembali kebentuk semula setelah diberi suatu tekanan (Zurriyati, 2011). Nilai rata-rata panelis terhadap tekstur sosis daging sapi dapat dilihat pada Gambar 3.

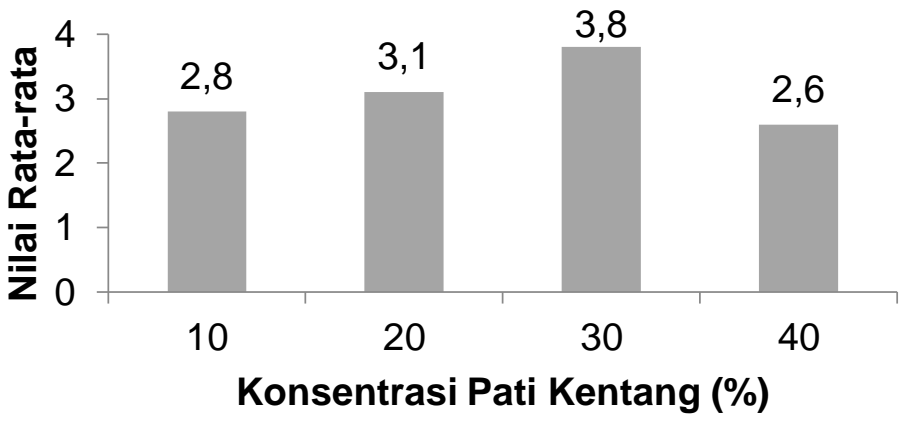

\section{Gambar 3. Nilai Rata-rata Kesukaan Tekstur}

Dari grafik pada Gambar 3 diatas, nilai rata-rata panelis terhadap kesukaan tekstur berkisar antara 2.6-3.8 (tidak suka-suka). Nilai rata-rata terendah sebesar 2.6 dengan karakteristik produk amat sangat kenyal diperoleh dari sosis daging sapi dengan konsentrasi pati kentang sebesar $40 \%$, sedangkan nilai rata-rata tertinggi sebesar 3.8 dengan karakteristik produk kenyal diperoleh dari sosis daging sapi dengan konsentrasi pati kentang $30 \%$. 
Sosis daging sapi dengan konsentrasi pati kentang 30\% memiliki tekstur kenyal, sehingga sosis ini paling disukai oleh panelis. Tekstur tersebut akibat dari sifat pati kentang sebagai filler dengan kandungan amilopektin. Tingginya kandungan amilopektin tersebut yang berpotensi dalam pembentukan sifat kekenyalan.

\section{Rasa}

Rasa adalah kualitas sensori yang berkaitan dengan indera perasa. Rasa juga didefinisikan sebagai rangsangan yang dirasakan oleh indera pengecap dan pembau apabila ada suatu bahan yang dimakan (Nisa dan Wardani, 2016). Nilai rata-rata panelis terhadap rasa sosis daging sapi tersaji pada Gambar 4 dibawah ini.

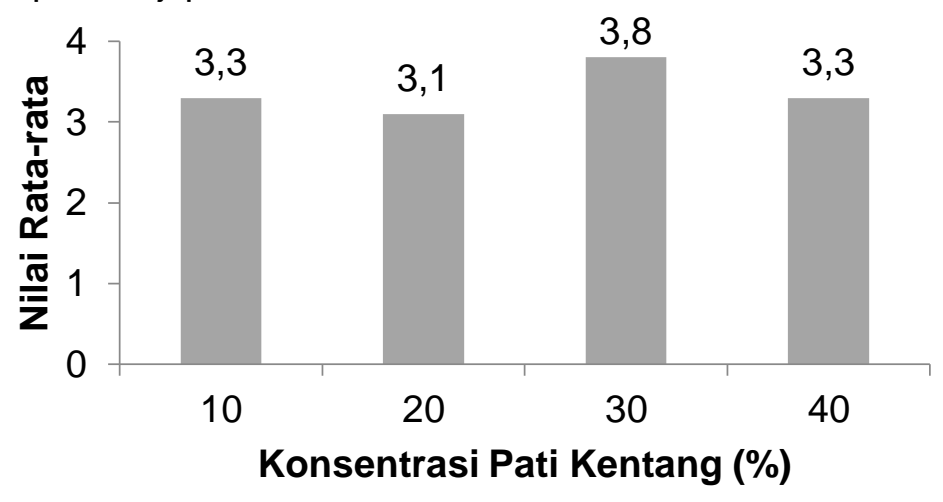

Gambar 4. Nilai Rata-rata Kesukaan Rasa

Dari grafik pada Gambar 4 diatas, nilai rata-rata panelis terhadap kesukaan rasa berkisar antara 3.1-3.8 (biasa-suka). Nilai rata-rata terendah sebesar 3.1 dengan karakteristik produk sangat gurih diperoleh dari sosis daging sapi dengan konsentrasi pati kentang sebesar $20 \%$, sedangkan nilai rata-rata tertinggi sebesar 3.8 dengan karakteristik produk gurih diperoleh dari sosis daging sapi dengan konsentrasi pati kentang $30 \%$.

Rasa sosis daging sapi yang sangat gurih maupun agak tidak gurih kurang disukai oleh panelis karena penggunaan jumlah bahan pengisi yang kurang tepat. Panelis lebih menyukai sosis daging sapi yang berasa gurih saja, yaitu pada konsentrasi pati kentang $30 \%$. Rasa daging sapi dan bahan penyedap dapat semakin tidak terasa apabila konsentrasi pati kentang sebagai bahan pengisi yang digunakan semakin banyak. Begitu pula sebaliknya, rasa akan semakin kuat apabila penggunaan bahan pengisi yang semakin sedikit.

\section{SIMPULAN}

Simpulan dari hasil penelitian ini yaitu secara keseluruhan, karakteristik sosis daging sapi dengan penambahan pati kentang memiliki warna merah dan berbintik, aroma daging dan rempah, tekstur kenyal, dan rasa gurih.

Sosis daging sapi dengan konsentrasi pati kentang 30\% memperoleh nilai kesukaan tertinggi pada seluruh atribut yaitu sebesar 27 pada atribut warna dengan rata-rata nilai 4.5 (agak tidak kemerahan dengan bintik merah), sebesar 21 pada atribut aroma dengan ratarata nilai 3.5 (daging dan rempah), sebesar 23 pada atribut tekstur dengan rata-rata nilai 3.8 (kenyal dan agak tidak berserat), dan sebesar 23 pada atribut rasa dengan rata-rata nilai 3.8 (gurih).

\section{DAFTAR PUSTAKA}

Ahmadi, K., Afrila, A., \& Adhi, W. I. (2007). Pengaruh Jenis Daging dan Tingkat Penambahan Tepung Tapioka yang Berbeda terhadap Kualitas Bakso. Buana Sains, 7(2), 139-144. Ariyani, F. R. (2006). Sifat Fisik dan Palatabilitas Sosis Daging Sapi dengan Penambahan Karagenan. Institut Pertanian Bogor.

Atma, Y. (2015). Studi Penggunaan Angkak sebagai Pewarna Alami dalam Pengolahan Sosis 
Daging Sapi. Jurnal Teknologi, 7(2), 76-85.

Badan Pusat Statistik. (2018). Produksi Tanaman Sayuran 2018. Retrieved February 10, 2020, from https://www.bps.go.id/indicator/55/61/2/produksi-tanaman-sayuran.html

Badan Standardisasi Nasional. (2015). Sosis Daging SNI 3820:2015. Jakarta, Indonesia: Badan Standardisasi Nasional.

Faturohman, T., Susilo, A., \& Mustakim. (2018). Pengaruh Penggunaan Tepung yang Berbeda terhadap Tekstur, Kadar Protein, Kadar Lemak, dan Organoleptik pada Bakso Daging Kelinci. Maduranch, 3(1), 29-34.

Gumilar, J., Rachmawan, O., \& Nurdyanti, W. (2011). Kualitas Fisikokimia Naget Ayam yang Menggunakan Filer Tepung Suweg (Amorphophallus campanulatus B1) (Physicochemical Quality of Chicken Nugget Using Suweg (Amorphophallus campanulatus B1) Flour as Filler). Jurnal Ilmu Ternak, 11(1), 1-5. https://doi.org/10.24198/jit.v11i1.393

Hidayat, B., Ahza, A. B., \& Sugiyono. (2007). Karakterisasi Tepung Ubi Jalar (Ipomoea batas L.) Varietas Shiroyutaka serta Kajian Potensi Penggunaannya Sebagai Sumber Pangan Karbohidrat Alternatif. Jurnal Teknologi Dan Industri Pangan, 18(1), 32-39.

Maulida, K. E. (2018). Sifat Fiskokimia Pati Kentang (Solanumn tuberosum L.) Varietas Medians Termodifikasi Cross-Linking yang Dipengaruhi Variasi Konsentrasi Monosodium Phosphate (MSP) dan Ketinggian Penanaman yang Berbeda. Universitas Pasundan.

Niken H., A., \& Adepristian Y., D. (2013). Isolasi Amilosa dan Amilopektin dari Pati Kentang. Jurnal Teknologi Kimia Dan Industri, 2(3), 57-62.

Nisa, A. K., \& Wardani, A. K. (2016). Pengaruh Lama Pengasapan dan Lama Fermentasi terhadap Sosis Fermentasi Ikan Lele (Claris gariepinus). Jurnal Pangan Dan Agroindustri, 4(1), 367-376.

Prastini, A. I., \& Widjanarko, S. B. (2015). Pembuatan Sosis Ayam Menggunakan Gel Porang (Amorphopallus mueleri Blume) sebagai Bahan Pengikat terhadap Karakteristik Sosis. Jurnal Pangan Dan Agroindustri, 3(4), 1503-1511.

Prayitno, A. H., Miskiyah, F., Rachmawati, A. V., Baghaskoro, T. M., Gunawan, B. P., \& Soeparno. (2009). Karakteristik Sosis dengan Fortifikasi $\beta$-Caroten dari Labu Kuning (Cucurbita moschata). Buletin Peternakan, 33(2), 111-118.

Sofyan, I. (2018). Pengaruh Konsentrasi Bahan Pengisi dan Sodium Tripholy Phosphate (Na5P3O10) terhadap Karakteristik Sosis Jamur Tiram Putih (Pleurotus ostreatus). Pasundan Food Technology Journal, 5(1), 25-36. https://doi.org/10.23969/pftj.v5i1.807

Timotious, K. H. (2004). Produksi Pigmen Angkak oleh Monascus. Jurnal Teknologi Dan Industri Pangan, 15(1), 79-86.

Wahyuni, D., Setiyono, \& Supadmo. (2012). Pengaruh Penambahan Angkak dan Kombinasi Filler Tepung Terigu dan Tepung Ketela Rambat terhadap Kualitas Sosis Sapi. Buletin Peternakan, 36(3), 181. https://doi.org/10.21059/buletinpeternak.v36i3.1627

Winarno, F. G. (1997). Kimia Pangan dan Gizi. Jakarta: Gramedia Pustaka Utama.

Zurriyati, Y. (2011). Palatabilitas Bakso dan Sosis Sapi Asal Daging Segar, Daging Beku, dan Produk Komersial. Jurnal Peternakan, 8(2), 49-57. 